\title{
The influence of temperature and light intensity on grain growth in relation to the carbohydrate and nitrogen economy of the wheat plant
}

\author{
J. H. J. Spiertz \\ Department of Field Crops and Grassland Husbandry, Agricultural University, \\ Wageningen, the Netherlands
}

Accepted: 27 May 1977

Key words: Grain growth, temperature, light intensity, carbohydrates, nitrogen content, dry matter distribution, harvest index

\section{Summary}

The response of grain growth to temperature and light intensity was studied under controlled conditions within the ranges from 10 to $25^{\circ} \mathrm{C}$ and from 64 to $188 \mathrm{~W} \mathrm{~m}^{-2}$, respectively. Warmth hastened the senescence of the wheat plant and enhanced the initial growth rate of the grains. Additional light promoted the rate of grain growth more at high than at low temperatures; under the latter conditions there was a considerable accumulation of carbohydrates in the stem (up to $40 \%$ ) from anthesis onwards. The rate of grain growth ranged from 0.70 to $1.64 \mathrm{mg}^{\mathrm{a}} \mathrm{yy}^{-1} \mathrm{kernel}^{-1}$. The duration of grain growth was prolonged by decreasing the temperature from 25 to $10{ }^{\circ} \mathrm{C}$; the increase in growth duration from about 30 to 80 days corresponded with a relatively stable temperature sum. Temperature and light also affected the redistribution of assimilates and the chemical composition of the grain. The rate of protein synthesis was promoted more by warmth than the rate of starch synthesis. This resulted in an increased nitrogen content of the grain. The final content of total non-structural carbohydrates (starch and sugars) was slightly decreased by warmth. Additional light raised the carbohydrate content of all parts of the plant and so decreased the nitrogen content of these parts. However, light intensity had less effect on nitrogen distribution and yield than temperature had.

\section{Introduction}

From site to site and from year to year great variations in light energy and temperature occur during the grain-filling period of wheat. Lower radiation during this period affects grain growth by decreasing photosynthesis and the supply of assi- 
milates (Willey \& Holliday, 1971; Fischer, 1975). The effect of temperature on grain growth is more complex than the effect of light intensity: there are effects on 'source' processes (e.g. earlier senescence of the leaves) and on 'sink' processes (e.g. faster initial growth rate of the kernels). Usually a rise in temperature shortens the kernel-filling period and decreases the final grain yield (Thorne, 1973; Sofield et al., 1974; Spiertz, 1974; Ford \& Thorne, 1975; Meredith \& Jenkins, 1976). The importance of the various components and aspects involved in the physiology of grain growth has been extensively reviewed by Evans \& Wardlaw (1976).

This paper presents the results of an experiment in which the main objectives were to investigate the influence of light energy and temperature on grain growth and on the distribution of assimilates, in relation to the carbohydrate and nitrogen economy of the wheat plant during the grain-filling period.

\section{Materials and methods}

The experiment was carried out in the phytotron of the Department of Field Crops and Grassland Husbandry of the Agricultural University, Wageningen.

\section{Plant material and growth conditions}

Seeds of the spring wheat variety Orca with a diameter of at least $2.6 \mathrm{~mm}$ were used for the experiment. To prevent seedborne diseases, the seeds were dressed with Quinolate V-4. Twenty seeds were sown at random per pot; about two weeks after emergence the number of seedlings was reduced to 15 per pot of $300 \mathrm{~cm}^{2}$.

Each pot contained $5 \mathrm{~kg}$ of sandy soil. Chemical analysis of this soil gave the following data: $\mathrm{pH}_{\mathrm{Kcl}} 5.7 ; \mathrm{K}$-value $6.0 ; \mathrm{P}$-value 25 ; organic matter content $4.1 \%$. The pots were fertilized weekly or fortnightly with a mineral solution of $\mathrm{NH}_{4} \mathrm{NO}_{3}$, $\mathrm{Ca}\left(\mathrm{NO}_{3}\right)_{2}, \mathrm{KNO}_{3}, \mathrm{KH}_{2} \mathrm{PO}_{4}$ and $\mathrm{MgSO}_{4}$. The total amount of minerals (in meq per pot) for the whole growing period was: $210 \mathrm{~N}$ (ratio $\mathrm{NH}_{4}+\mathrm{NO}_{3}-$ was $1: 2.5$ ), $60 \mathrm{P}$, $120 \mathrm{~K}, 30 \mathrm{Ca}, 30 \mathrm{Mg}$, and $30 \mathrm{~S}$. The micro-elements were applied twice.

During the growing period, insecticides and fungicides were applied regularly to keep the plants healthy.

\section{Arrangement of experiments}

From sowing to ear emergence (12 March to 15 June) the plants were grown in a greenhouse with natural daylength and temperature controlled at 12 and $8{ }^{\circ} \mathrm{C}$ for day and night, respectively.

Just before ear emergence the plants were transferred to growth rooms. The temperature was kept at $15^{\circ} \mathrm{C}$ and the daylength at 16 hours.

From flowering (29 June) onwards, 12 temperature/light intensity combinations were imposed as follows:

- 4 temperatures $\left({ }^{\circ} \mathrm{C}\right): 10\left(\mathrm{t}_{1}\right), 15\left(\mathrm{t}_{2}\right), 20\left(\mathrm{t}_{3}\right)$ and $25\left(\mathrm{t}_{4}\right)$

- 3 light intensities $\left(\mathrm{W} \mathrm{m}{ }^{-2} ; 0.4-0.7 \mathrm{~nm}\right): 188\left(\mathrm{~L}_{1}\right), 118\left(\mathrm{~L}_{2}\right)$ and $64\left(\mathrm{~L}_{3}\right)$.

The daily quantities of light energy $\left(\mathrm{MJ} \mathrm{m}^{-2}\right)$ intercepted on different heights during a 16-hour light period 3 weeks after flowering were: 


$\begin{array}{llrll} & & L_{1} & L_{\mathbf{2}} & L_{3} \\ \text { level just above the plants } & ( \pm 2.00 \mathrm{~m}) & 10.80 & 6.82 & 3.68 \\ \text { level of the ears } & ( \pm 1.80 \mathrm{~m}) & 8.58 & 5.02 & 2.80 \\ \text { level of the flag leaves } & ( \pm 1.60 \mathrm{~m}) & 4.81 & 2.68 & 1.39 \\ \text { level of the second leaves } & ( \pm 1.40 \mathrm{~m}) & 1.93 & 0.96 & 0.42 \\ \text { level of the plant base } & ( \pm 1.00 \mathrm{~m}) & 1.05 & 0.46 & 0.13\end{array}$

The relative humidity was kept between 80 and $90 \%$ with the higher values for the 10 and $15{ }^{\circ} \mathrm{C}$ treatments and the lower values for the 20 and $25^{\circ} \mathrm{C}$ treatments.

\section{Sampling and observations}

Plants were sampled at various times by harvesting 4 pots per treatment; most of the observations were made on the main culms. To determine dry matter weights and leaf area the culms were separated into

a) flag leaf, penultimate leaf, other green leaves and dead leaves;

b) peduncle, penultimate and remaining internodes;

c) ear (chaff and grains).

The side culms were separated into ears and straw. Stubble and root weights were determined together for all culms per pot.

The coefficients of variation ranged from 2.7 to $14.4 \%$ for the various dry weight observations.

\section{Determining the photosynthesis and respiration rates}

Photosynthetic and respiratory rates were determined with an infrared gas analyser (URAS, Hartmann Brown Co., Frankfurt am Main) by enclosing leaves and ears in an assimilation chamber. The tube-shaped chamber was $40 \mathrm{~cm}$ long and $25 \mathrm{~mm}$ wide. The measurements were made under the light conditions in the growth room. The temperature of the air in the chamber was adjusted to $20^{\circ} \mathrm{C}$ when determining the photosynthetic rate and adjusted to the temperature of the different treatments for determining the respiratory rates.

The air passed through the chamber at a rate of $3.81 \mathrm{~min}^{-1}$ and a $\mathrm{CO}_{2}$ concentration of about $325 \mu 1^{1-1}$. The rates of photosynthesis and respiration were calculated from the difference in $\mathrm{CO}_{2}$ concentration in the air between inlet and outlet of the chamber.

\section{Determining nitrogen and sugar content}

The samples of the different parts of the plant were dried at $70{ }^{\circ} \mathrm{C}$ to a constant weight. The dried material was ground through a $1-\mathrm{mm}$ sieve and stored in air-tight plastic bags. To determine total nitrogen, a modified Kjeldahl method was used.

To determine water-soluble carbohydrates, $500 \mathrm{mg}$ of dried material was boiled in $50 \mathrm{ml}$ water for 10 minutes. After cooling, $5 \mathrm{ml}$ of a mixed solution of $238 \mathrm{~g}$ zinc acetate $+30 \mathrm{~g}$ acetic acid, dissolved in $1000 \mathrm{ml}$ of water were added. One minute later, $5 \mathrm{ml}$ of a solution of $106 \mathrm{~g} \mathrm{~K}_{4} \mathrm{Fe}(\mathrm{CN})_{6} \cdot 3 \mathrm{H}_{2} \mathrm{O}$, dissolved in $1000 \mathrm{ml}$ of water were added. This mixture was made up to $100 \mathrm{ml}$ with water and filtered; $5 \mathrm{ml}$ of filtrate were diluted with water and used for the determination of the total soluble 
carbohydrates with anthrone by means of an auto-analyser.

To determine the starch content, $250 \mathrm{mg}$ of dried material were used; after being boiled in water the samples were treated for 2 hours in an autoclave at $120^{\circ} \mathrm{C}$ and $149 \mathrm{~cm}$ water pressure. After cooling, $2.5 \mathrm{ml}$ of acetate buffer and $10 \mathrm{mg}$ amyloglucosidase per $100 \mathrm{mg}$ (expected) starch were added. This solution was made up to $50 \mathrm{ml}$ with water and placed in a waterbath at $60{ }^{\circ} \mathrm{C}$ for one hour. After cooling, the samples were treated similarly to the analysis of the water-soluble carbohydrates.

Total soluble carbohydrate and starch content were expressed in glucose units.

\section{Results}

Influence of light intensity and temperature after anthesis on the area of green parts of the plants, photosynthetic activity and respiration

The total green area of the main culm at anthesis was composed of $152 \mathrm{~cm}^{2}$ of leaf area, $80 \mathrm{~cm}^{2}$ of stem area and an undetermined area of the ear. Both flag leaf and penultimate leaf had an area of $54 \mathrm{~cm}^{2}$, whilst the dry weights amounted to 163 and $145 \mathrm{mg}$ per leaf, respectively. The green area of the two side culms per plant was not determined. It was found that warmth hastened the senescence of the leaves and the yellowing of the other green organs (Table 1). At $25^{\circ} \mathrm{C}$ the senescence was almost completed after 4 weeks, whilst at $10^{\circ} \mathrm{C}$ there remained some green leaf area even after 11 weeks.

Light intensity also had a slight influence; the green coloration lasted longer at low light intensities.

The rate of uptake of $\mathrm{CO}_{2}$ (apparent photosynthesis) of the flag leaf was about $23.5 \mathrm{mg} \mathrm{dm}^{-2} \mathrm{~h}^{-1}$ at ear emergence; at anthesis this value had decreased to about
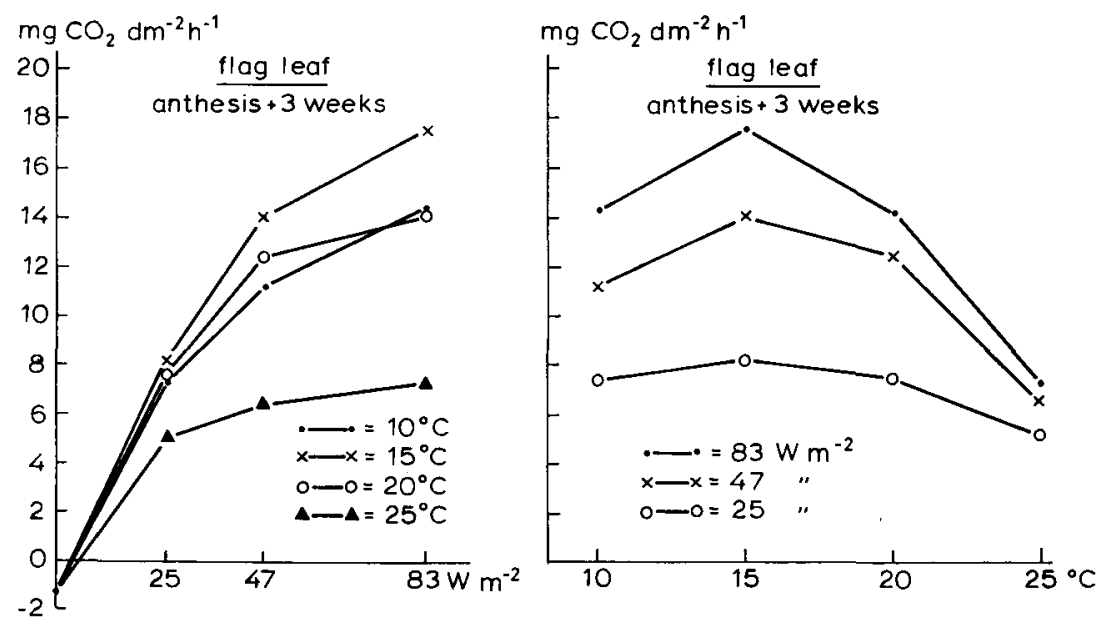

Fig. 1. The rate of apparent photosynthesis of the flag leaf at 3 weeks after anthesis in relation to the post-floral temperature and light treatments.

Neth. J. agric. Sci. 25 (1977) 
Table 1. Amount of green area of the flag leaves expressed as percentage of the leaf area at anthesis.

\begin{tabular}{llll}
\hline Temperature $\left({ }^{\circ} \mathrm{C}\right)$ & Anthesis +2 weeks & Anthesis +4 weeks & Anthesis +6 weeks \\
10 & 100 & 85 & 42 \\
15 & 100 & 69 & 36 \\
20 & 100 & 31 & 0 \\
25 & 100 & 2 & 0 \\
\hline
\end{tabular}

$21.5 \mathrm{mg}$. During the first few weeks after anthesis the rate of photosynthesis remained constant per unit green area at all temperatures except $25^{\circ} \mathrm{C}$. At 3 weeks after anthesis the $15^{\circ} \mathrm{C}$ treatment showed the highest rate of photosynthesis (Fig. 1). The decrease in photosynthetic rate at higher temperatures may have been caused by faster ageing of the leaves, whilst the photosynthetic rate at $10{ }^{\circ} \mathrm{C}$ may have been limited by the slow-down of metabolic processes and the very high carbohydrate content of the vegetative organs.

The rate of dark respiration of the flag leaf at ear emergence and anthesis amounted to $6.0 \%$ and $4.8 \%$ of the rate of apparent photosynthesis, respectively. Soon after anthesis the rate of respiration of the ear and the flag leaf increased in response to warmth. However, at 3 weeks after anthesis the rate of respiration of the ear decreased with a rise in temperature. The respiration rate of the ear was $1.11,1.49,1.17$ and $0.63 \mathrm{mg} \mathrm{CO}_{2}$ per $\mathrm{g}$ dry weight per hour with $10,15,20$ and $25^{\circ} \mathrm{C}$, respectively.

In this experiment the production of assimilates depended mainly on:

- light intensity: fixed at 3 levels;

- rate of photosynthesis per unit green area;

- amount and duration of the green area per culm.

Although the few measurements of photosynthesis and respiration do not allow a complete carbohydrate balance to be made, we might conclude from the data of Table 1 and Fig. 1, that temperature affected the duration of green area per culm more than net photosynthesis. Therefore the total production of assimilates after anthesis is favoured by low temperatures, combined with high light intensities.

\section{Influence of light intensity and temperature after anthesis on grain growth and dry matter distribution}

After anthesis, warmth reduced the duration of stem and grain growth (Fig. 2). The stem weight increased more at lower temperatures, so there was a surplus of assimilates for grain growth. After the mid kernel-filling stage the senescence of the leaves had already proceeded to a large extent, decreasing the production of assimilates. The reduced supply of assimilates from photosynthesis was partly compensated by a retranslocation of assimilates from the stem to the grains. The average decrease in stem weight was $30 \%$ of the final kernel weight.

The weight of the leaves decreased only slightly after anthesis. However, warmth reduced the weight of the roots considerably during the kernel-filling period.

There were significant interaction effects of light and temperatures on grain 

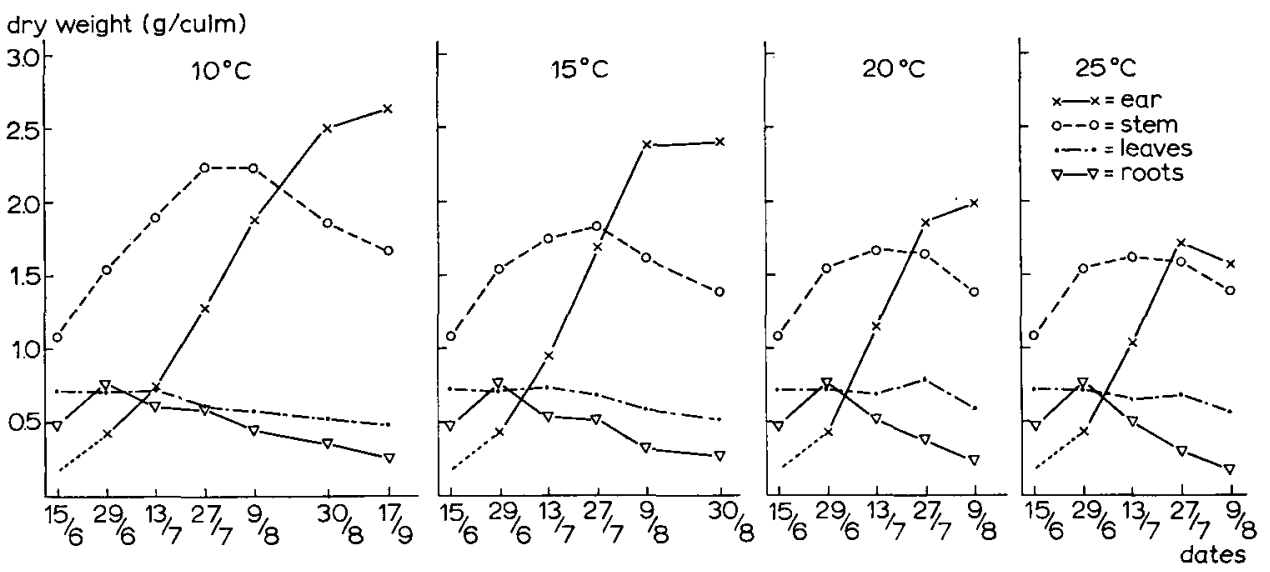

Fig. 2. Dry matter weights of the various parts of the main culm from heading onwards.

growth. The growth rate of the kernels during the apparently linear phase of grainfilling varied within a range from 30 to $74 \mathrm{mg}$ per ear per day. Differences in grain growth due to the reduction of light intensity were less at lower than at higher temperatures (Table 2).

Faster grain growth due to warmth was set off by accelerated senescence of the plants and resulted in a decrease of grain yields (Fig. 3). The post-floral period was shortened from about 80 to 30 days. However, the sum of daily temperatures during the kernel-filling proved to be relatively constant. At ripeness it seemed that the temperature sum was somewhat lower at high temperatures. This may have been caused by shortage of water or assimilates.

Grain growth per degree-day was about the same during the initial phase of kernel filling. After 300 degree-days the growth curves deviated from the $10{ }^{\circ} \mathrm{C}$ curve in the sequence 25,20 and $15^{\circ} \mathrm{C}$. From the point of deviation until maximum kernel weight was attained, the growth rate was not determined by temperature, but predominantly by the supply of assimilates.

Grain yields per ear ranged from 0.79 to $2.56 \mathrm{~g}$ because of the effects of temperature and light intensity on the rate and the duration of grain growth. Differences in grain yield per ear were not only attributable to the effects of light and temper-

Table 2. The rate of grain growth $\left(\mathrm{mg} \mathrm{day}^{-1}\right)$ during the linear phase of grain filling, at different light intensities.

\begin{tabular}{|c|c|c|c|c|c|c|}
\hline \multirow{2}{*}{$\begin{array}{l}\text { Temperature } \\
\left({ }^{\circ} \mathrm{C}\right)\end{array}$} & \multicolumn{2}{|c|}{$188 \mathrm{~W} \mathrm{~m}^{-2}$} & \multicolumn{2}{|c|}{$118 \mathrm{~W} \mathrm{~m}^{-2}$} & \multicolumn{2}{|c|}{$64 \mathrm{~W} \mathrm{~m}^{-2}$} \\
\hline & per ear & per kernel & per ear & per kernel & per ear & per kernel \\
\hline 10 & 43 & 0.86 & 41 & 0.82 & 30 & 0.70 \\
\hline 15 & 52 & 1.04 & 43 & 0.91 & 34 & 0.80 \\
\hline 20 & 64 & 1.31 & 47 & 1.04 & 38 & 0.93 \\
\hline 25 & 74 & 1.64 & 54 & 1.29 & 48 & 1.23 \\
\hline
\end{tabular}



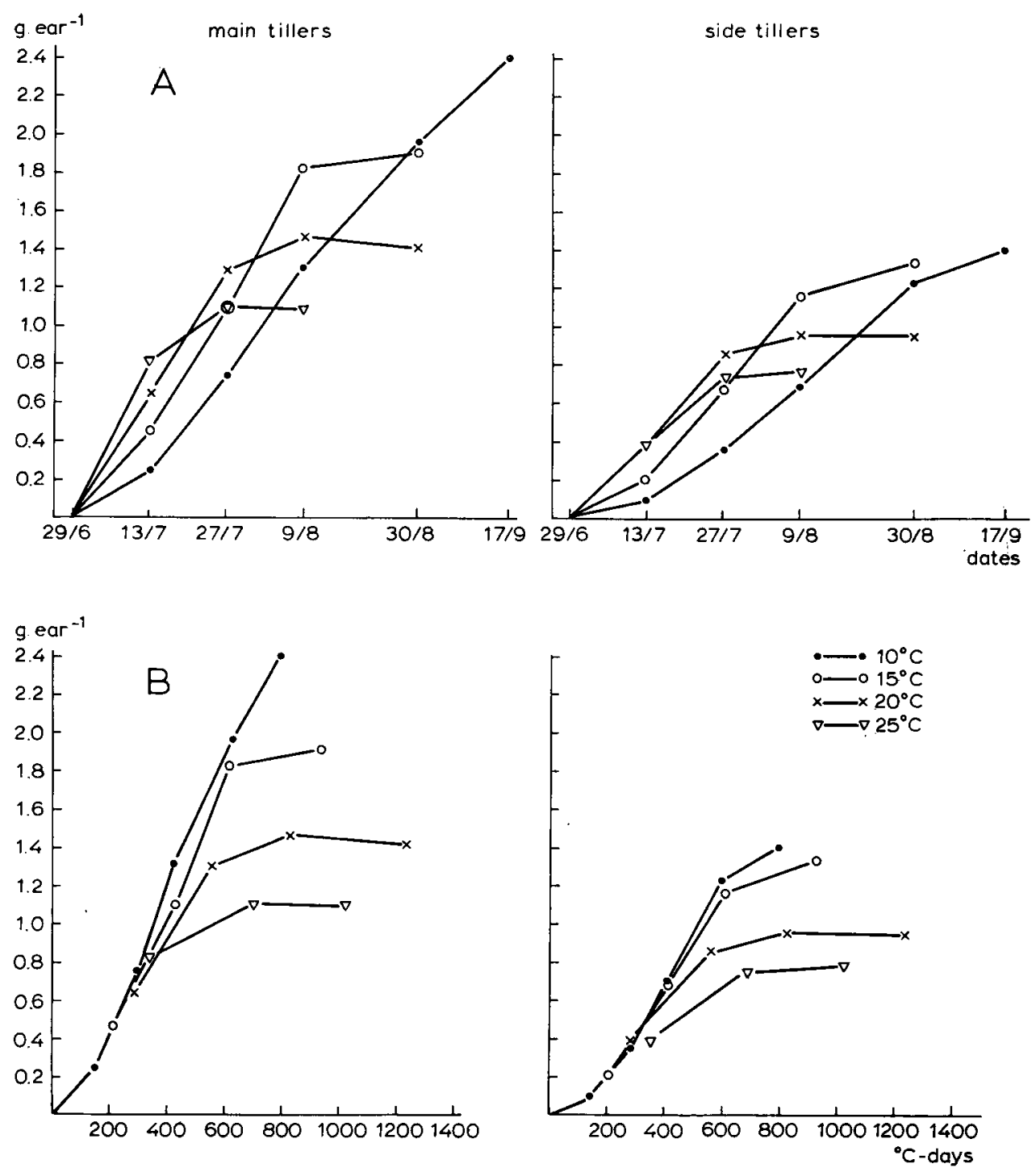

Fig. 3. Grain growth at 4 temperatures, expressed as g dry matter per ear against time (A) and against the sum of daily temperatures after anthesis (B).

ature on the grain weight per kernel, but also to the number of kernels per ear. Obviously, reduced light intensity and warmth after anthesis caused many embryos to be aborted, thereby decreasing the number of kernels per ear (Table 3). Thus the effects of temperature and light were more pronounced on grain yield per ear than on kernel weight. Harvest index increased, when growing conditions (a relatively low temperature combined with a high light intensity) were more favourable 
Table 3. Grain yield and yield components of main culms.

\begin{tabular}{lllllll}
\hline $\begin{array}{l}\text { Light } \\
\text { intensity } \\
(\mathrm{W} \mathrm{m}-2)\end{array}$ & $\begin{array}{l}\text { Temp- } \\
\text { erature } \\
\left({ }^{\circ} \mathrm{C}\right)\end{array}$ & $\begin{array}{l}\text { Weight/ } \\
\text { kernel } \\
(\mathrm{mg})\end{array}$ & $\begin{array}{l}\text { Kernels/ } \\
\text { ear }\end{array}$ & $\begin{array}{l}\text { Grain } \\
\text { weight/ } \\
\text { ear }(\mathrm{g})\end{array}$ & $\begin{array}{l}\text { Dry matter/ } \\
\text { culm }(\mathrm{g})\end{array}$ & $\begin{array}{l}\text { Harvest } \\
\text { index }(\%)\end{array}$ \\
188 & 10 & 48.9 & 52.3 & 2.56 & 5.23 & \\
& 15 & 43.6 & 49.3 & 2.15 & 4.62 & 46.9 \\
& 20 & 37.5 & 49.0 & 1.83 & 4.34 & 42.2 \\
& 25 & 32.0 & 44.5 & 1.42 & 3.81 & 37.3 \\
118 & 10 & 49.7 & 49.3 & 2.44 & 5.15 & 47.6 \\
& 15 & 45.8 & 44.9 & 2.06 & 4.46 & 46.2 \\
& 20 & 31.9 & 44.0 & 1.40 & 3.94 & 35.6 \\
& 25 & 26.6 & 42.5 & 1.13 & 3.56 & 31.7 \\
64 & 10 & 38.0 & 46.8 & 1.78 & 4.04 & 44.6 \\
& 15 & 31.9 & 42.8 & 1.36 & 3.86 & 35.4 \\
& 20 & 26.1 & 41.3 & 1.08 & 3.37 & 32.0 \\
& 25 & 20.3 & 39.0 & 0.79 & 3.15 & 25.1 \\
\hline
\end{tabular}

for a long period of photosynthetic activity. In this experiment the harvest index ranged from 0.25 to 0.49 .

Influence of light intensity and temperature after anthesis on water-soluble carbohydrates (w.s.c.) and starch

Carbohydrates are the main substrate for starch synthesis in the grain. The amount of available carbohydrates in the wheat plant after flowering depends on the balance between photosynthetic production and utilization of assimilates.

In this phytotron experiment the carbohydrate economy was more affected by temperature (range $10-25^{\circ} \mathrm{C}$ ) than by light intensity (range $64-188 \mathrm{~W} \mathrm{~m}^{-2}$ ). The changes in starch and w.s.c. contents during the post-floral period are shown in Fig. 4.

The rate of starch synthesis was strongly enhanced by warmth and less by light intensity. The effect of light intensity on starch synthesis was greater at high than at low temperatures.

Although the percentage of w.s.c. in the kernels differed considerably because of temperature, the amount of w.s.c. was about equal for all temperature treatments during the first two weeks after anthesis. A high percentage of w.s.c. in the grain resulted from a lower rate of grain growth. Conversely, a high starch content in the grain was associated with increased grain growth due to warmth. Where the growth rate of the grains was accelerated by a higher light intensity, the starch content was hardly affected. Thus the rate at which sugars were converted into starch was determined by temperature.

The final contents of total non-structural carbohydrates were $21.3,20.4,16.2$ and $16.5 \%$ sugar and $65.1,62.2,58.5$ and $53.5 \%$ starch at temperatures of 10 , 15,20 and $25^{\circ} \mathrm{C}$, respectively. 
starch

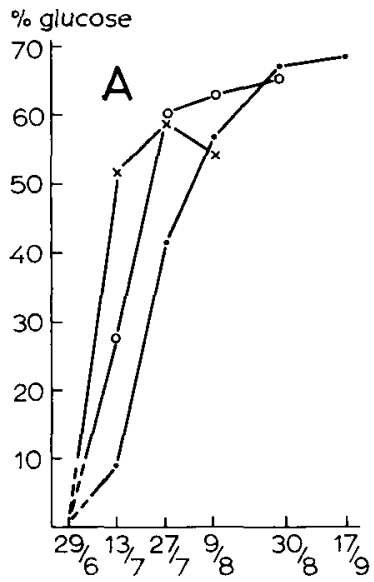

starch

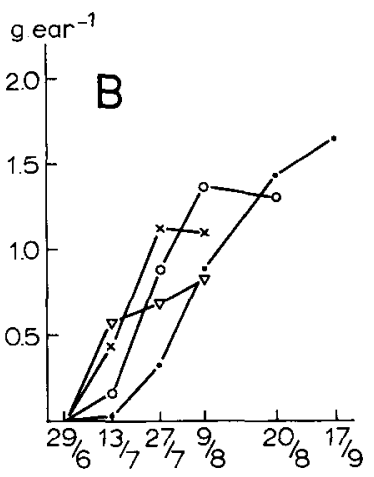

water-soluble sugars

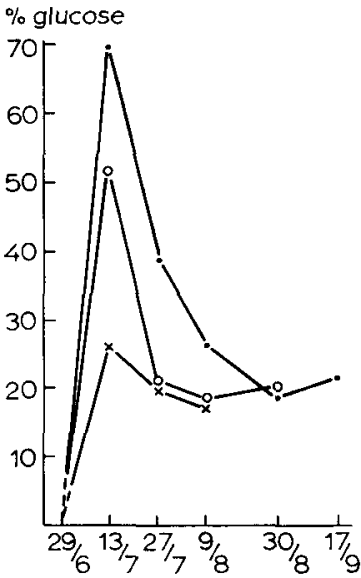

water-soluble sugars

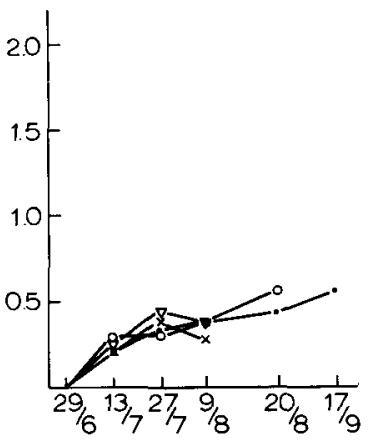

nitrogen

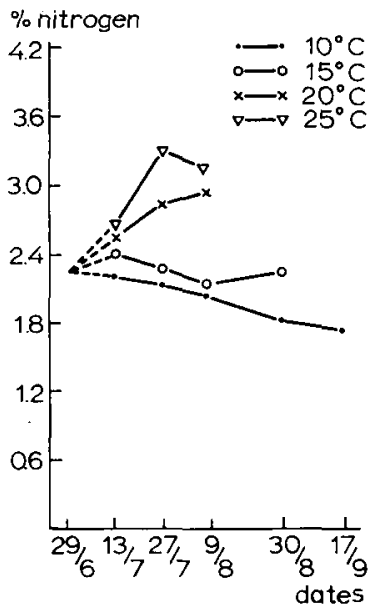

total non-structural carbohydrates

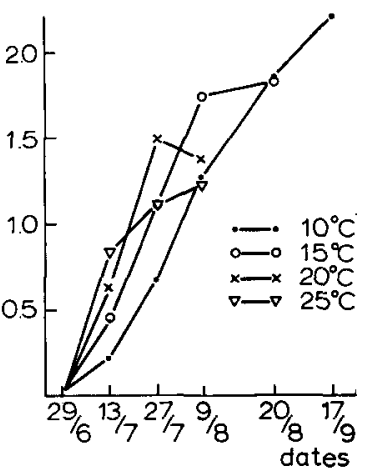

Fig. 4A. The percentage of non-structural carbohydrates in the grain at three temperature treatments (the $25{ }^{\circ} \mathrm{C}$ treatment is omitted, because samples were missing) and the percentage of nitrogen in the grain at four temperature treatments.

Fig. 4B. The accumulation of non-structural carbohydrates in the grain.

The w.s.c. content in the various vegetative organs of the wheat plant was also strongly affected by temperature (Fig. 6). At lower temperatures the w.s.c. content of the stem increased considerably after flowering. There was also a marked increase of the w.s.c. content of the upper leaves after flowering. The w.s.c. content of the roots and stubbles likewise responded to lower temperatures by increasing markedly.

The influences of temperature and light intensity on the storage capacity of the grains and on the amount of w.s.c. reserves available for grain growth in stem and leaves are shown in Fig. 5. As there was a considerable accumulation of carbo- 

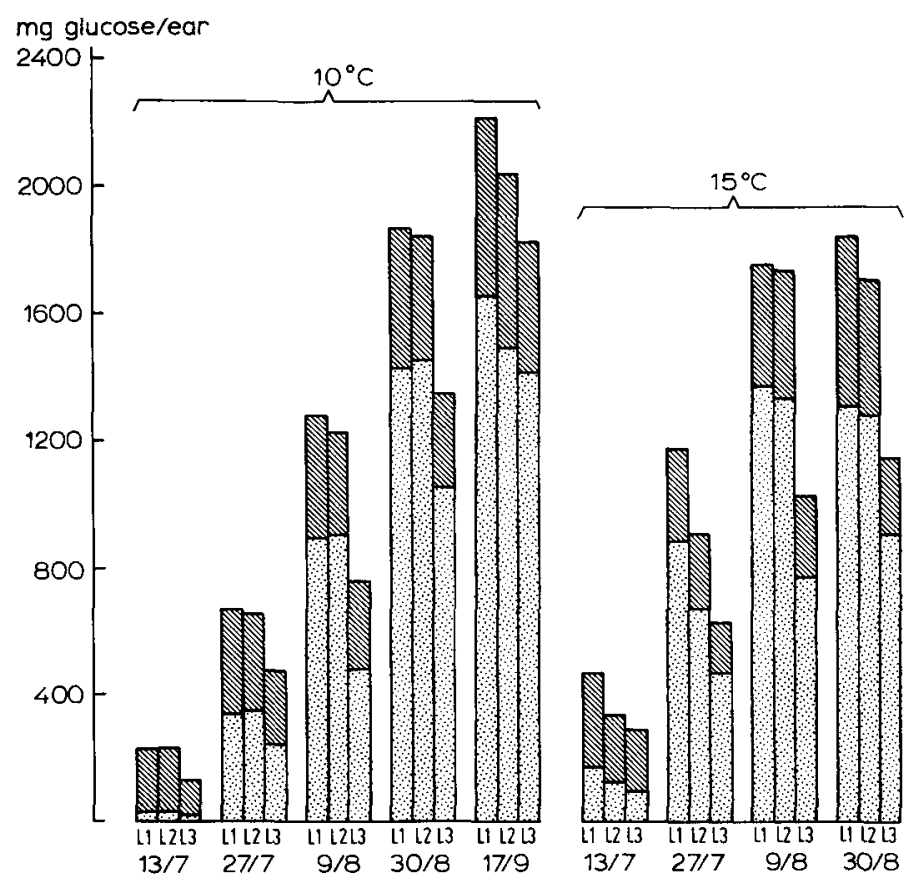

GRAIN
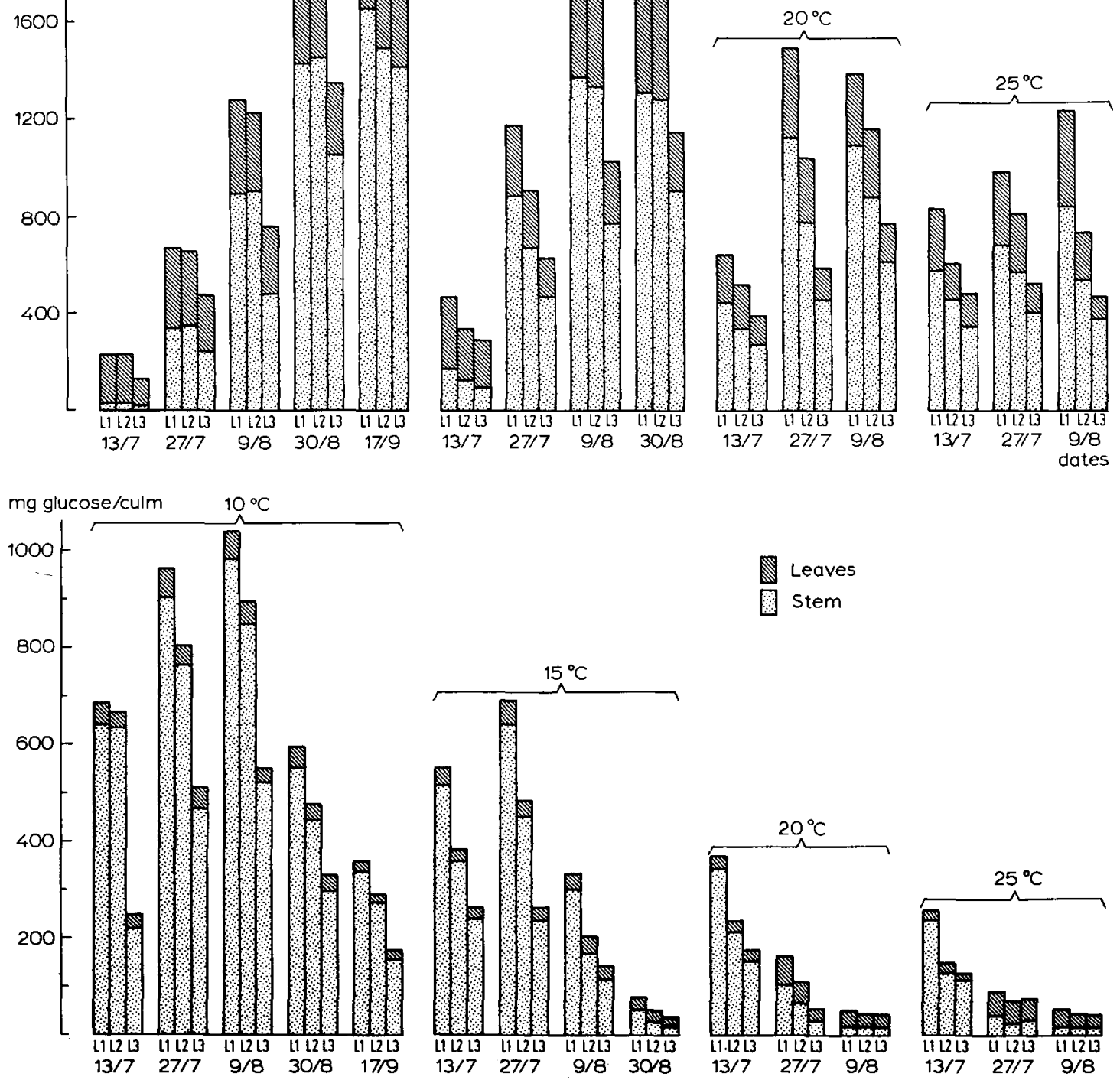

Fig. 5. The amount of non-structural carbohydrates in the stem and the leaves and in the grain of the main culm during the post-floral period at four temperature and three light treatments. 

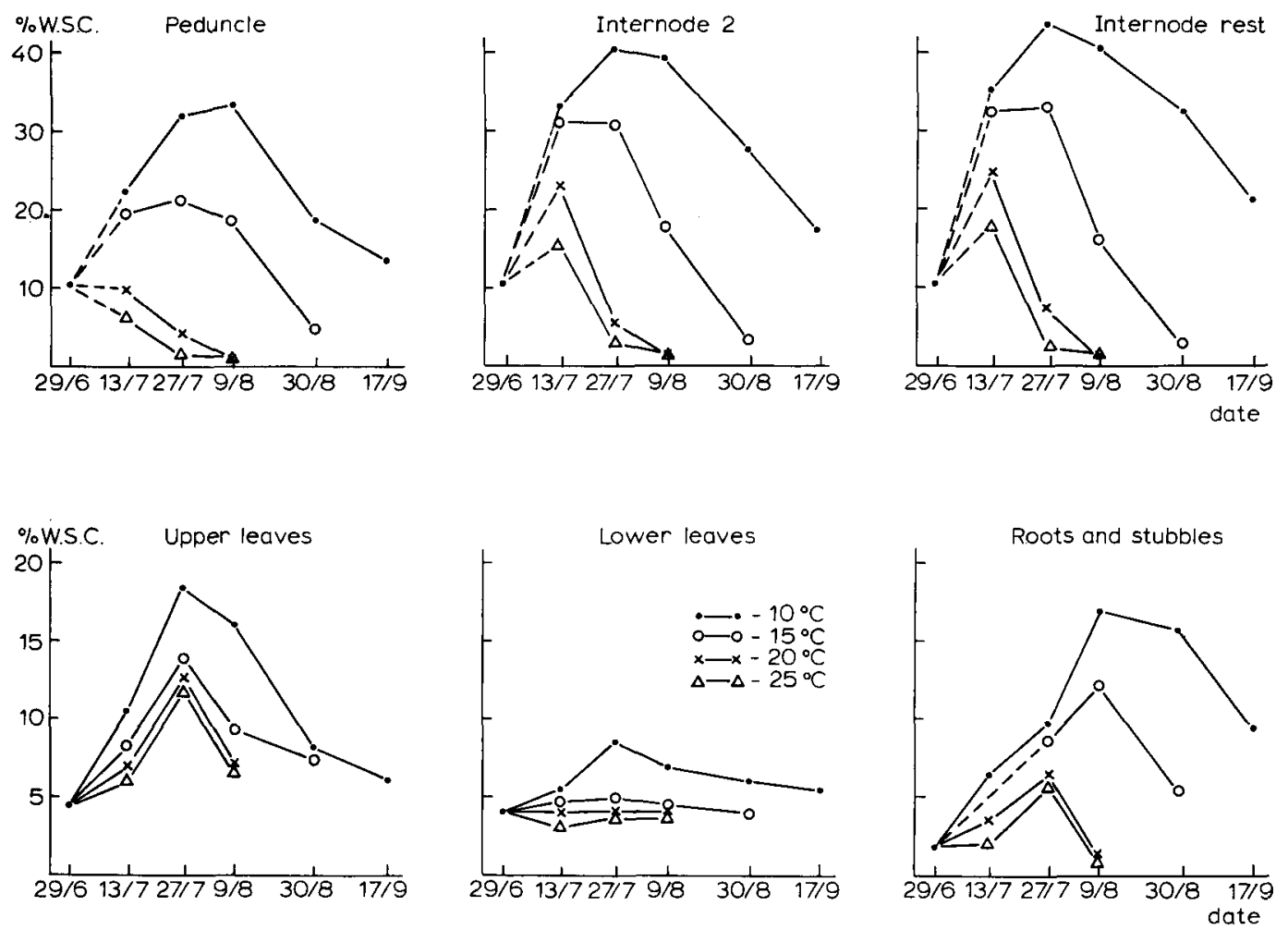

Fig. 6. The percentages of water-soluble carbohydrates in the vegetative organs of the main culm during the post-floral period.

hydrates in the stem at lower temperatures, it may be inferred that the growth rate of the grains was affected more by temperature than by the supply of assimilates. The leaves were of minor importance as an alternative sink for carbohydrates.

High light intensities and low temperatures both increased the amount of w.s.c. in the grains.

Influence of light intensity and temperature after anthesis on nitrogen uptake and distribution

Samples of plant parts, viz leaf blades, internodes (including leaf sheaths) and ears (grains and chaff), were taken at regular intervals from anthesis onwards. There was only a slight influence of light intensity on the nitrogen content of the leaves and stem. The nitrogen percentage of the leaves decreased during the post-floral period: on average from 3.8 to $0.8 \%$ for the flag leaf and from 2.0 to $0.9 \%$ for the lower leaves. Temperature affected the rate at which the nitrogen content of the leaves declined. The average decrease of the nitrogen percentages of the peduncle, internode 2 and lower internodes was from 1.50 to $0.35 \%$, from 0.65 to 

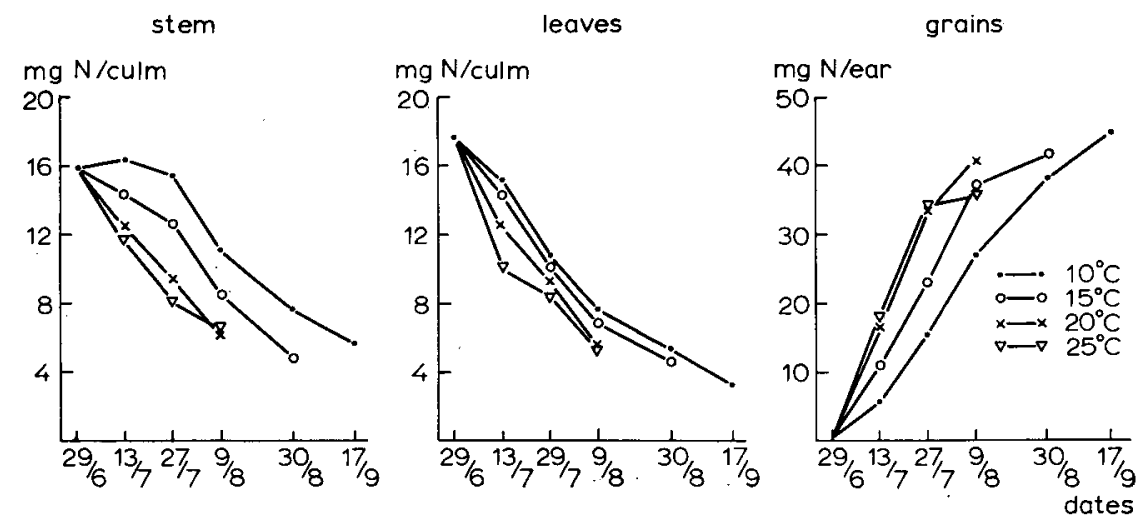

Fig. 7. The amount of nitrogen compounds in the leaves, stem and grain of the main culm during the post-floral period in relation to the four temperature treatments.

$0.25 \%$ and from 0.50 to $0.25 \%$, respectively. The rate of decline was accelerated by warmth; a reduced light intensity gave a slightly higher nitrogen percentage of all internodes.

Warmth enhanced the rate of uptake of nitrogen in the grain from 0.6 to $1.2 \mathrm{mg}$ $\mathrm{N}$ per ear per day within the range from 10 to $20{ }^{\circ} \mathrm{C}$. A further increase of temperature did not raise the nitrogen uptake. Enhanced uptake of nitrogen by the grains was associated with accelerated depletion of the nitrogen reserves in the stem and the leaves (Fig. 7). The contribution of the nitrogen reserves in stem and leaves

Table 4. Nitrogen content of the grain and nitrogen uptake and distribution within the main culm.

\begin{tabular}{llllllll}
\hline $\begin{array}{l}\text { Light } \\
\text { intensity } \\
\left(\mathrm{W} \mathrm{m}{ }^{-2}\right)\end{array}$ & $\begin{array}{l}\text { Temp- } \\
\text { erature } \\
\left({ }^{\circ} \mathrm{C}\right)\end{array}$ & $\begin{array}{l}\text { mg N per } \\
\text { culm one } \\
\text { week after } \\
\text { anthesis }\end{array}$ & $\begin{array}{l}\text { mg N per } \\
\text { culm at } \\
\text { harvest }\end{array}$ & $\begin{array}{l}\text { mg N in } \\
\text { straw }\end{array}$ & $\begin{array}{l}\mathrm{mg} \mathrm{N} \text { in } \\
\text { grain }\end{array}$ & $\begin{array}{l}\text { Nitrogen } \\
\text { index }\end{array}$ & $\begin{array}{l}\% \mathrm{~N} \text { in } \\
\text { grain }\end{array}$ \\
188 & 10 & 40.7 & 53.5 & 11.3 & 42.2 & 0.79 & 1.65 \\
& 15 & 37.2 & 50.8 & 12.5 & 38.3 & 0.75 & 1.78 \\
& 20 & 37.1 & 53.4 & 13.1 & 40.3 & 0.75 & 2.20 \\
& 25 & 33.8 & 51.8 & 13.7 & 38.1 & 0.74 & 2.68 \\
118 & 10 & 40.7 & 56.5 & 11.1 & 45.4 & 0.80 & 1.86 \\
& 15 & 39.6 & 53.1 & 12.3 & 40.8 & 0.77 & 1.98 \\
& 20 & 34.0 & 52.1 & 13.7 & 38.4 & 0.74 & 2.74 \\
& 25 & 34.1 & 49.3 & 14.7 & 34.6 & 0.70 & 3.06 \\
64 & 10 & 41.1 & 51.5 & 13.1 & 38.4 & 0.75 & 2.16 \\
& 15 & 41.3 & 51.0 & 14.4 & 36.6 & 0.72 & 2.69 \\
& 20 & 37.5 & 54.0 & 15.1 & 38.9 & 0.72 & 3.60 \\
& 25 & 29.5 & 48.1 & 16.9 & 31.2 & 0.65 & 3.95 \\
\hline
\end{tabular}


accounted for no more than about $60 \%$ of the nitrogen yield of the grains, so there must have been an additional supply of nitrogen to the grains from nitrogen uptake by the plant after anthesis (Table 4). The nitrogen yields of the grains differed only slightly, as did the nitrogen quantities left in the straw. This was all the more striking because of the great effect of temperature on the dry matter yield of the grains.

\section{Discussion}

The results of this experiment confirm the more general finding that high postanthesis temperatures hasten senescence of the wheat plant, shorten the growth period and decrease total dry matter weight as well as grain yield (Thorne et al., 1968; Sofield et al., 1974; Spiertz, 1974; Ford \& Thorne, 1975). This shorter growth period was associated with a faster initial growth rate of the grains and an accelerated movement of carbohydrates and proteins from the vegetative organs to the developing grains. Ford et al. (1976) demonstrated that the effects of warmth on processes related to grain growth were caused by the temperature of the ears themselves, rather than of the whole plant.

Although temperature is very important, light intensity also affects grain growth. Contrary to the conclusion reached by Ford \& Thorne (1975), we found a considerable interaction between temperature and light intensity on the growth rate of the grains. During the linear phase of grain filling the growth rate was increased more by additional light at high than at low temperatures (from 0.70 to 0.86 per day per kernel at $10{ }^{\circ} \mathrm{C}$ and from 1.23 to $1.64 \mathrm{mg}$ per day per kernel at $25^{\circ} \mathrm{C}$ with an increase in light intensity from 64 to $188 \mathrm{~W} \mathrm{~m}^{-2}$ ). At high temperatures the demands of the grains required more assimilates than the amount produced under the conditions of reduced light intensity. At low temperatures there are ample carbohydrate reserves in the stem. Nevertheless the rate of grain growth increased with additional light. So one might conclude that assimilates from current photosynthesis are more readily available for grain growth than are assimilates stored in the stem.

The temperature and light treatments from anthesis onwards also affected seed setting. High light intensities and low temperatures (growing conditions favouring a high level of carbohydrates in the plant), increased the number of kernels per ear. The importance of supply of assimilates for seed setting was also found in a $\mathrm{CO}_{2}$ enrichment experiment (Krenzer \& Moss, 1975). They found that kernel number and size were more dependent on additional assimilates at high than at low temperatures. Our results confirm the effect of temperature on the rate of grain growth found by Sofield et al. (1974), but do not correspond to their conclusion that differences in rate of grain growth per ear are due almost entirely to grain number per ear and not to radiation. There are other stimulating effects of light on grain growth besides an additional supply of assimilates; e.g. Wardlaw (1970) found that reduced light energy decreased the number of endosperm cells. We found a positive effect of light intensity, even with ample carbohydrate reserves, at the low temperature treatments.

The faster initial growth rate did not result from an increased net photosynthesis, but was mainly an effect of temperature on processes involved in grain growth. The 
actual growth of the kernels will be determined by the supply of assimilates and the rate at which low molecular substrates are converted to high molecular storage substances. In our experiment, starch and protein synthesis in the grains were considerably promoted by warmth up to $20^{\circ} \mathrm{C}$; a further rise in temperature to $25^{\circ} \mathrm{C}$ was less effective. Protein synthesis was enhanched more by warmth than was starch synthesis (see Fig. 4 and 7). This resulted in a higher nitrogen content in the seed. Kolderup (1975) also found that a rise in temperature increased grain nitrogen content considerably. Similar effects of temperature in the range from 10 to $23{ }^{\circ} \mathrm{C}$ have been found for protein and starch synthesis in pea seeds (Robertson et al., 1962).

Initially, more assimilates were produced than used for grain growth; therefore the reserves in the vegetative organs increased during the first weeks after anthesis. Later on the increased utilization of assimilates for grain growth and respiration caused the carbohydrate reserves in the stem to deplete rapidly, especially at high temperatures.

On average, the losses of carbohydrates and nitrogen from the stem and leaves amounted to about 30 and $60 \%$ of the ultimate quantities of carbon and nitrogen compounds in the grains respectively. However, the loss of carbohydrates cannot be completely attributable to retranslocation, it is partly caused by respiration. Rawson \& Evans (1971) estimated the loss due to respiration to be one-third of the change in stem weight. However, the respiration rate will depend on temperature and available substrate. Spiertz (1974) found a $Q_{10}$ value of about 2 for the respiration of different organs during the milk- to dough-ripe stage. This value was confirmed by more detailed studies of respiration by J. Vos (Dept. of Field Crops \& Grassland Husbandry, Agricultural University, Wageningen; pers. comm., 1976) recently; he found a $Q_{10}$ value of 2.0 one week after anthesis. Therefore the contribution of stem reserves to the starch accumulation in the grain must have been considerably lower than $30 \%$ of the ultimate grain yield. The percentage of watersoluble carbohydrates in the stem at the final harvest provides some evidence that the redistribution of carbohydrates was greater at higher temperatures.

Early studies on carbohydrate translocation (Miller, 1939) showed that sugars move into the grain until the moisture content falls to about $40 \%$. Sugars continue to be converted to starch while the desiccation of the kernel occurs. Not all sugars are converted to starch in the grain. Escalada \& Moss (1976) studied the changes in non-structural carbohydrate fractions of field-grown spring wheat. They found that the glucose, fructose and glucofructan contents reached maxima before the phase of rapid starch synthesis, but then decreased as the kernels matured. We found a similar pattern in w.s.c., but the percentage of w.s.c. attained relatively higher values ( \pm 15 à $20 \%$ ). The quantity of sugars remained constant during kernel-filling: this corresponds to data published by Jennings \& Morton (1963).

In contrast to the w.s.c. content, the starch content was relatively low, so a part of the polysaccharides was determined as 'water-soluble' carbohydrates instead of as starch. The percentage total non-structural carbohydrates (starch + w.s.c.) decreased with warmth. This was compensated for by an increase of the structural carbohydrates. However, the protein content also increased with warmth. Thus 
warmth not only affected dry weight, but also the chemical composition of the grain.

In our experiment, water and sugar uptake were affected both by temperature and by light intensity. The rate of desiccation was determined by temperature. It is not clear whether the water content is a reflection of ripening or actively affects ripening processes. Radley (1976) found that the water loss of the grains is preceded by an increase in the abscisic acid content. This endogenous growth substance might be a regulating agent in changing the biochemical and physical attributes of the pericarp, which are related to water loss of the grain. Jenner \& Rathjen (1975) stated that the onset of the decrease of starch accumulation in the grain is caused by a fall in the synthetic capacity of the endosperm and not by a reduction in the supply of sucrose to the sites of starch synthesis. They hypothesized that enzymic changes involved in converting sucrose to starch affect the duration of grain growth. We found that the kernel-filling period was longer as the levels of carbohydrates and proteins in the vegetative organs were higher and the grains had a higher water content. The high level of proteins might help prolong the photosynthetic activity of the leaves, and the available carbohydrates might promote the functioning of the roots.

The final grain yield depends both on the rate of dry matter accumulation and on the length of the grain-filling period. The duration of grain growth is determined by processes involved in the senescence of the vegetative organs and processes governing the ripening of the grain. The number of days between anthesis and maximum kernel weight, the so-called 'effective grain-filling period', amounted to $81,63,41$ and 29 days corresponding to temperature treatments of $10,15,20$ and $25^{\circ} \mathrm{C}$, respectively. Grain growth per unit of degree-day was the same with all temperature treatments until 300 degree-days. From that point onwards the decline in the growth curve ocurred in the sequence $25,20,15$ and $10^{\circ} \mathrm{C}$. One might conclude that at high temperatures the rapid senescence of the green tissue and the high respiration caused a shortage of carbohydrates, which reduced the growth rate towards the end of the kernel filling. At lower temperatures under more optimal growing conditions, we observed that the ripening of the ears preceded the senescence of the top leaves.

An analysis of yield differences of field-grown wheat crops in different seasons has shown positive effects of warmth on the rate of grain growth (Spiertz, in preparation). Positive effects of warmth on the efficiency, defined as grain-leaf ratio, were also found with a field-grown crop by Welbank et al. (1968). The importance of light intensity in a field crop was studied extensively by Willey \& Holliday (1971) and Fischer (1975) in shading experiments. The significance of light intensity is over-estimated in this type of experiment because of the effect of shading on the temperature of the wheat plant. In spite of these difficulties, the results of field and phytotron experiments agree well.

Grain yields of wheat might be enhanced if wheat plants were better adapted to hot spells during the kernel-filling period. This would allow the wheat plant to benefit more from the higher light intensity that is mostly associated with warmth. 


\section{Acknowledgments}

The author wishes to thank Mr J. Ellen for technical assistance with the performance of the experiment and Mrs Evelyn Zantman and Mrs Corry de Wit for chemical analyses. The author wishes also to acknowledge the encouragement and advice of Ir L. J. P. Kupers and Prof Dr Ir G. J. Vervelde and the helpful comments of his colleagues in the preparation of the manuscript.

\section{References}

Escalada, J. A. \& D. N. Moss, 1976. Changes in nonstructural carbohydrate fractions of developing spring wheat kernels. Crop Sci. 16: 627-631.

Evans, L. T. \& I. F. Wardlaw, 1976. Aspects of the comparative physiology of grain yield in cereals. Adv. Agron. 28: 301-359.

Fischer, R. A., 1975. Yield potential in a dwarf spring wheat and the effect of shading. Crop Sci. 15: 607-613.

Ford, M. A., I. Pearman \& G. N. Thorne, 1976. Effects of variation in ear temperature on growth and yield of spring wheat. Ann. appl. Biol. 82: 317-333.

Ford, M. A. \& G. N. Thorne, 1975. Effects of variation in temperature and light intensity at different times on growth and yield of spring wheat. Ann. appl. Biol. 80: 283-299.

Jenner, C. F. \& A. J. Rathjen, 1975. Factors regulating the accumulation of starch in ripening wheat grain. Aust. J. Pl. Physiol. 2: 311-322.

Jennings, A. C. \& R. K. Morton, 1963. Changes in carbohydrate, proteïn and non-proteïn nitrogenous compounds of developing wheat grain. Aust. J. biol. Sci. 16: 318-331.

Kolderup, F., 1975. Effects of temperature, photoperiod and light quantity on protein production in wheat grains. J. Sci. Fd Agric. 26 (5) 583-592.

Krenzer, E. G. \& Dale N. Moss, 1975. Carbon dioxide enrichment effects upon yield and yield components in wheat. Crop Sci. 15: 71-74.

Meredith, P. \& L. D. Jenkins, 1976. The developing starch granule. 3. The filling of the wheat grain. N.Z. Jl Sci. 19 (1) 115-123.

Miller, E. C., 1939. A physiological study of the winter wheat plant at different stages of its development. Bull. Kansas St. Coll. Technol. 47.

Radley, M., 1976. The development of wheat grain in relation to endogenous growth substances. J. exp. Bot. 27: 1009-1021.

Rawson, H. M. \& L. T. Evans, 1971. The contribution of stem reserves to grain development in a range of wheat cultivars of different height. Aust. J. agric. Res. 22: 851-863.

Robertson, R. N., H. R. Highkin, J. Smydzuk \& F. W. Went, 1962. The effect of environmental conditions on the develoment of pea seeds. Aust. J. biol. Sci. 15: 1-15.

Sofield, I., L. T. Evans \& I. F. Wardlaw, 1974. The effects of temperature and light on grain filling in wheat. In: Mechanisms of regulation of plant growth. Bull. Royal Soc. N.Z. 12: 909-915.

Spiertz, J. H. J., 1974. Grain growth and distribution of dry matter in the wheat plant as influenced by temperature, light energy and ear size. Neth. J. agric. Sci. 22: 207-220.

Thorne, G. N., M. A. Ford \& D. J. Watson, 1968. Growth, development and yield of spring wheat in artificial climates. Ann. Bot. 32: 425-445.

Thorne, G. N., 1973. Physiology of grain yield of wheat and barley. Rep. Rothamsted exp. Stn Part 2: 14-18.

Wardlaw, I. F., 1970. The early stages of grain development in wheat: response to light and temperature in a single variety. Aust. J. biol. Sci. 23: 765-774.

Welbank, P. J., K. J. Witts \& G. N. Thorne, 1968. Effect of radiation and temperature on efficiency of cereal leaves during grain growth. Ann. Bot. 32: 79-95.

Willey, R. W. \& R. Holliday, 1971. Plant population, shading and thinning studies in wheat. J. agric. Sci., Camb. 77: 453-461. 